\title{
The Gender Gap in Higher Education in Alaska
}

\author{
JUDITH KLEINFELD $^{1,2}$ and JUSTIN J. ANDREWS ${ }^{1}$
}

(Received 28 February 2006; accepted in revised form 15 June 2006)

\begin{abstract}
A gender gap strongly favoring women is occurring in higher education throughout the Arctic and is especially severe among indigenous groups. This study documents the size, nature, and recent increase in the gender gap at the University of Alaska, especially for Alaska Native students. To our knowledge, this is the first study to provide statistical documentation of this phenomenon. We find that among Alaska Natives, women are earning bachelor's degrees at almost three times the rate of men and associate degrees at almost five times the rate of men. Furthermore, the gender gap in favor of females widened between 1998 and 2004, the most recent year for which we have information. The experience at the University of Alaska shows that increasing access and providing college preparation and support services alone are not enough to engage indigenous young men in postsecondary education. What may also be needed are ways of making education more compatible with traditional male cultural roles and community values. The Community Trades Technology Program at the University of Alaska has succeeded in enrolling large numbers of young Native men in a postsecondary program through such an educational model. The program 1) is located in the students' home community; 2) offers cohort-based instruction that enrolls most of the students' friends; 3) emphasizes practical, hands-on knowledge and the lore of the trade; 4) embeds academic instruction in practical tasks, such as writing letters about construction supplies; 5) connects the educational program to immediate employment in construction projects scheduled for the community; and 6) provides practical help to people, such as doing home repairs, without charge.
\end{abstract}

Key words: educational achievement, school success, gender roles, gender gap, gender differences, gender role expectations, Alaska Natives

RÉSUMÉ. En matière d'études supérieures dans l'Arctique, il existe un écart prononcé entre les sexes, écart qui se montre en faveur des femmes et se manifeste surtout dans les groupes indigènes. Ce document porte sur l'ampleur, la nature et l'accroissement récent de l'écart entre les sexes à l'Université de l'Alaska, plus particulièrement chez les étudiants autochtones de l'Alaska. À notre connaissance, il s'agit de la première étude à fournir de la documentation statistique au sujet de ce phénomène. Nous avons constaté qu'au sein des Autochtones de l'Alaska, les femmes décrochent un baccalauréat au moins trois fois plus souvent que les hommes, et des diplômes associés au moins cinq fois plus souvent que les hommes. De plus, l'écart entre les sexes en faveur des femmes s'est intensifié entre 1998 et 2004, l'année la plus récente pour laquelle nous possédons de l'information. L'expérience de l'Université de l'Alaska indique que l'amélioration de l'accès et la prestation de services de préparation et de soutien ne suffisent pas à attirer les jeunes hommes à faire des études postsecondaires. Ce qu'il faut probablement, c'est une façon de rendre l'éducation plus compatible avec les rôles traditionnels et culturels de l'homme, ainsi qu' avec les valeurs communautaires. Le programme communautaire de technologies et de métiers (Community Trades Technology Program) de l'Université de l'Alaska a réussi à recueillir les inscriptions de grands nombres de jeunes hommes autochtones dans un programme postsecondaire grâce à un modèle d'études de ce genre. Le programme 1) est donné au sein de la collectivité même des étudiants; 2) est caractérisé par des cours dispensés à la cohorte, qui est composée principalement des amis des étudiants; 3) met l'accent sur des connaissances pratiques et manuelles, ainsi que sur l'attrait des métiers; 4) intègre l'instruction théorique aux tâches pratiques, comme la rédaction de correspondance au sujet de matériaux de construction; 5) établit un lien entre le programme d'études et des emplois immédiats dans le cadre de travaux de construction prévus dans la région; et 6) fournit de l'aide pratique visant à aider les gens, en faisant des réparations à domicile par exemple et ce, gratuitement.

Mots clés : réalisation scolaire, réussite scolaire, rôles en fonction des sexes, écart entre les sexes, différences entre les sexes, attentes selon les rôles en fonction des sexes, Autochtones de l'Alaska

Traduit pour la revue Arctic par Nicole Giguère.

\footnotetext{
${ }^{1}$ Northern Studies Program, University of Alaska, P.O. Box 756460, Fairbanks, Alaska 99775-6460, U.S.A.

${ }^{2}$ Corresponding author: ffjsk@uaf.edu

(C) The Arctic Institute of North America
} 


\section{INTRODUCTION}

The fact that in the United States far more women than men are now enrolling in and graduating from postsecondary educational programs is well documented (Freeman, 2004). In 1970 only 68 women enrolled in American colleges and universities for every 100 men (Sum et al., 2003). Women achieved equality in university enrollment in 1978, and since then, women have outnumbered men each year by ever-increasing margins. The U.S. Department of Education's National Center for Education Statistics projects that by 2013, there will be 135 women enrolled in American postsecondary institutions for every 100 men (Gerald and Hussar, 2003, mid-range projections).

Except for Asian-Americans, the gender gap in postsecondary achievement in the United States is significantly larger in minority groups than it is in the white population. In 2000, white women earned 131 bachelor's degrees for every 100 bachelor's degrees conferred on white men (Sum et al., 2003). Among Hispanics, that gap widens to 148 bachelor's degrees awarded to women for every 100 awarded to men, and among African-Americans, 192 bachelor's degrees were awarded to women for every 100 awarded to men. To clarify, what is occurring in the United States as a whole is not an absolute decline in the proportion of male high school graduates choosing to pursue higher education. Rather, it is a dramatic increase in the proportion of the female population choosing to pursue higher education, while the proportion of the male population making the same decision has increased only slightly.

\section{Gender Gap in the Arctic}

The gender gap in postsecondary education is a phenomenon occurring in many nations in the world, particularly in nations with robust post-industrial economies, such as those in Western Europe. For circumpolar nations, there is statistical documentation of the gender gap in postsecondary education for general populations, but corresponding information about indigenous people is not available. According to the United Nations' 2004 Human Development Report, 154 women enrolled in tertiary educational programs in Sweden for every 100 men (a ratio of 1.54:1). In Norway, the ratio of women to men in such programs is 1.52:1; in Canada, 1.34:1; in Russia, 1.33:1; and in Finland, 1.22:1 (UN, 2004). The largest disparity occurs in Iceland, where women outnumber men in postsecondary programs at the ratio of $1.74: 1$. While information for Greenland is not provided in the Human Development Report or in any other official documents we could locate, enrollment data provided to the authors by administrators at Ilisimatusarfik, Greenland's only university, reveal an especially large gender gap of 160 women for every 100 men (E. Janussen, pers. comm. 2006). In postsecondary programs in Alaska, which constitutes the circumpolar presence of the United States, the ratio of women to men is 1.49:1 (Sum et al., 2003).
Again, these United Nations statistics do not differentiate between indigenous and non-indigenous peoples, and the differences may be substantial. When we inquired about gender disparities at Norway's Sámi University College, which offers higher education for Sámi in Norway, Sweden, Finland, and Russia, a staggering gender disparity was reported-in 2003, Sámi women outnumbered Sámi men by more than 5:1 (K. Nystad, pers. comm. 2006). In Nunavut, women outnumber men at the predominantly Inuit Nunavut Arctic College (which offers twoyear and certificate programs) by more than $2: 1$, according to a newspaper article (Minogue, 2005a). Such personal communications and newspaper articles, as well as concerns voiced by indigenous university administrators, such as the executive dean of the University of Alaska's College of Rural and Community Development (B. Joseph, pers. comm. 2005), suggest a serious gender gap among indigenous people. However, we are aware of no systematic documentation of this issue for any circumpolar region or nation. The present study documents the size, nature, and recent increase of the postsecondary gender gap for both indigenous and general populations in Alaska, speculates on its causes, and describes an educational model that might alleviate the problem for indigenous young men. The gender gap, which affects employability, income, political leadership, marriage patterns, social problems, and sustainability, is of growing concern to Alaska's indigenous communities.

\section{THE UNIVERSITY OF ALASKA'S EFFORTS TO ENROLL ALASKA NATIVE STUDENTS}

The University of Alaska system, with enrollment of nearly 35000 students, is the only public institution of higher education in Alaska. In addition to the three main campuses in Fairbanks, Anchorage, and Juneau, the university system includes 12 satellite campuses located in regional hubs throughout the state, as well as a robust distance learning program that brings higher education to many Alaska Native villages. The university places a high priority on attracting Alaska Native students to higher education and provides extensive support to these students once they enroll. The flagship campus in Fairbanks, for example, has a robust Rural Student Services program, several Alaska Native clubs and organizations, and residence facilities sponsored by Native organizations and designed to ease the transition from village to university life.

The University of Alaska has devoted intense effort and substantial institutional resources to encouraging Alaska Native high school students, especially those from isolated rural villages, to enroll in postsecondary education. The Rural Alaska Honors Institute (RAHI), for example, is a full-scholarship six-week intensive college-preparatory program designed to attract rural Alaska Native students and ease their transition to the urban university environment. Using a far-flung recruitment strategy that targets 
TABLE 1. Male graduates of all ethnic groups as percent of total graduates of the University of Alaska system in 2004, by degree level

\begin{tabular}{lccc}
\hline \hline & Male Graduates & Total Graduates & \% Male \\
\hline Certificate & 45 & 159 & 28 \\
Associate & 295 & 843 & 35 \\
Bachelor's & 445 & 1223 & 36 \\
Master's & 197 & 428 & 46 \\
Doctorate & 19 & 36 & 53 \\
\hline \hline
\end{tabular}

schools and counselors and a word-of-mouth campaign, RAHI brings promising high school students from remote regions of Alaska to the Fairbanks campus over the summer. It has developed many strategies designed to help students make the academic and social transition from high school to college, such as offering them the opportunity to take up to three courses during that summer that earn full college credit.

In another effort to attract students from every part of the state, the University of Alaska offers $\$ 11000$ scholarships to the top $10 \%$ of the graduating class of every high school in Alaska. This program greatly increases the accessibility of a college education to Alaska Native students, many of whom attend small high schools in rural villages and thus are over-represented in students from the top $10 \%$ of the graduating class in high schools across the state. Regional Native organizations that administer social service programs also routinely provide college scholarships to indigenous students from their regions.

In short, the opportunity to go to pursue higher education is widely available to both male and female Native students throughout Alaska.

\section{METHODS}

The data presented in this report were provided by the University of Alaska Statewide Office of Budget and Institutional Research, using special computer runs of internal enrollment data, with full cooperation and funding from the University's Office of Student Enrollment Services. These analyses are based on institutional records for fiscal year 2003 (autumn 2003 to spring 2004). When referring to graduates, we use the designation 2004 (the year students graduated), but when discussing enrollment patterns, we use the year 2003. Enrollment information from special programs, such as Construction Trades Technology, the Rural Alaska Honors Institute, and the Alaska Scholars programs, was provided by the programs themselves from their internal records. Once analyzed, the data and their implications were discussed with Native educators at the University of Alaska Fairbanks; Native educators in Anchorage, in a special meeting convened by the Institute of Social and Economic Research; and later with the university's Board of Regents and other university offices. Alaska Native educators are well aware of the gender gap in postsecondary education; they are working to understand and address this problem and collaborating on additional research.

The analyses reported here have the limitation of omitting those Alaska Native students who go out of state for higher education, whose exact numbers and gender distribution are unknown. However, the extreme gender gap noted among RAHI graduates, who attend colleges and universities outside Alaska as well as within the state, suggests that the patterns we have documented for the University of Alaska system can be generalized to Alaska Native youth as a population group.

\section{RESULTS}

\section{Gender Gap at the University of Alaska Among All Students}

In 2003, men constituted $52 \%$ of Alaska's population over the age of 18, the largest proportion of men in any American state (see Kleinfeld and Andrews, 2005 for statistical tables and details). That same year, however, men comprised only 39\% of the student body in the University of Alaska system. Translated into figures comparable to the United Nations Human Development Report, the University of Alaska enrolled approximately 157 female students for every 100 male students in 2003. In the size of its gender gap in enrollment, Alaska ranks third among the 50 United States (Sum et al., 2003). This gap increases dramatically in rural campuses, most of which have a predominantly Alaska Native enrollment. At the university's campus in the remote northwestern Alaskan community of Kotzebue, for example, 266 women enrolled for every 100 men in 2003.

Once enrolled in the University of Alaska system, males are less likely than females to graduate. Males account for $35 \%$ of enrollment, but only $28 \%$ of graduates at the certificate program level; $36 \%$ of enrollment, but $35 \%$ of graduates at the associate program level; and $40 \%$ of enrollment, but only $36 \%$ of graduates at the bachelor's level (Table 1).

\section{Enrollment and Graduation of Alaska Native Males}

The gender gap in the University of Alaska system exists for all students, but is far more extreme for Alaska Native males, especially rural males. Of Alaska Native students who enrolled in the University of Alaska in 2003, $31 \%$ are male while $69 \%$ are female. Among rural Alaska Native students (in regions not accessible by the road or ferry system), only $27 \%$ are male while $73 \%$ are female.

The gender gap among indigenous students is far wider at certificate and associate levels (one- and two-year programs) than at the baccalaureate level (four-year programs). This is surprising, since the certificate and associate programs tend to be closer to villages, shorter, and more employment-oriented. We report these data in absolute numbers, rather than as ratios, since the numbers of 
TABLE 2. Degree recipients at the University of Alaska by ethnicity and fiscal year.

\begin{tabular}{|c|c|c|c|c|c|c|c|c|c|}
\hline Ethnicity & Degree & Gender & 1998 & 1999 & 2000 & 2001 & 2002 & 2003 & 2004 \\
\hline \multirow[t]{12}{*}{ Alaska Native/American Indian } & \multirow[t]{3}{*}{ Certificate } & Female & 73 & 36 & 47 & 24 & 41 & 34 & 62 \\
\hline & & Male & 16 & 14 & 12 & 7 & 8 & 7 & 16 \\
\hline & & $\%$ Male & 18 & 28 & 20 & 23 & 16 & 17 & 21 \\
\hline & \multirow[t]{3}{*}{ Associate } & Female & 58 & 49 & 51 & 56 & 55 & 60 & 102 \\
\hline & & Male & 13 & 16 & 21 & 15 & 27 & 21 & 21 \\
\hline & & \% Male & 18 & 25 & 29 & 21 & 33 & 26 & 17 \\
\hline & \multirow[t]{3}{*}{ Bachelor's } & Female & 60 & 55 & 78 & 71 & 68 & 89 & 67 \\
\hline & & Male & 25 & 32 & 32 & 19 & 26 & 26 & 27 \\
\hline & & \% Male & 29 & 37 & 29 & 21 & 28 & 23 & 29 \\
\hline & \multirow[t]{3}{*}{ Master's } & Female & 6 & 15 & 9 & 15 & 15 & 17 & 26 \\
\hline & & Male & 1 & 6 & 4 & 4 & 2 & 4 & 11 \\
\hline & & $\%$ Male & 14 & 29 & 31 & 21 & 12 & 19 & 30 \\
\hline \multirow[t]{12}{*}{ White } & \multirow[t]{3}{*}{ Certificate } & Female & 56 & 38 & 63 & 52 & 56 & 58 & 69 \\
\hline & & Male & 46 & 59 & 50 & 48 & 48 & 34 & 45 \\
\hline & & \% Male & 45 & 61 & 44 & 48 & 46 & 37 & 39 \\
\hline & \multirow[t]{3}{*}{ Associate } & Female & 390 & 400 & 371 & 395 & 349 & 391 & 391 \\
\hline & & Male & 263 & 222 & 182 & 187 & 260 & 230 & 241 \\
\hline & & \% Male & 40 & 36 & 33 & 32 & 43 & 37 & 38 \\
\hline & \multirow[t]{3}{*}{ Bachelor's } & Female & 659 & 643 & 575 & 586 & 608 & 588 & 602 \\
\hline & & Male & 450 & 381 & 394 & 389 & 385 & 351 & 398 \\
\hline & & $\%$ Male & 41 & 37 & 41 & 40 & 39 & 37 & 40 \\
\hline & \multirow[t]{3}{*}{ Master's } & Female & 207 & 225 & 216 & 178 & 168 & 185 & 243 \\
\hline & & Male & 168 & 122 & 153 & 110 & 124 & 166 & 155 \\
\hline & & \% Male & 45 & 35 & 41 & 38 & 42 & 47 & 39 \\
\hline
\end{tabular}

students in many comparisons are so small. In 2004, among Alaska Native graduates of certificate programs, 62 students were female compared to only 16 males; among graduates of associate degree programs, 102 were female compared to only 21 males; among graduates of baccalaureate programs, 67 were female compared to only 27 males; among graduates of master's degree programs, 26 were female compared to only 11 males (see Table 2 ). To put it another way, males earned less than one-third of the bachelor's degrees awarded to Alaska Natives, giving them the most extreme gender gap of any minority group in the United States (Sum et al., 2003). The gender gap in associate degree programs is almost five to one.

\section{Gender Differences among Alaska Natives at the Highest Levels of Academic Proficiency in High School}

The gender gap in academic engagement and success is evident far before Alaska Native students reach higher education. The Rural Alaska Honors Institute, as previously mentioned, was established to recruit promising Alaska Native high school students, offer them a free summer college preparation program at the University of Alaska Fairbanks, and provide subsequent encouragement and college guidance. Follow-up statistics from this program over many years offer information on the academic trajectories of the most academically proficient Alaska Native students, including those who have attended college outside Alaska.

According to program records, $66 \%$ of the 1036 students who have attended RAHI were female. Of those who have gone on to earn degrees, $100 \%$ of those obtaining doctorates (six RAHI alumni) have been female; $71 \%$ obtaining masters degrees have been female ( 15 females and 6 males); and 78\% obtaining bachelor's degrees have been female (132 females and 38 males). Even among those who graduate from the far shorter associate programs, $71 \%$ have been female (54 females and 22 males). Of certificate degree holders, $75 \%$ have been female ( 24 females and 8 males). These gender differences do not come from lack of attention. RAHI program administrators are well aware of the gender gap and have intensively recruited young Native males, but with only modest success.

A similar gender gap is evident in the Alaska Scholars program, which offers an $\$ 11000$ University of Alaska scholarship to the top $10 \%$ of each high school graduating class in Alaska. Among Alaska Scholars as a whole, nearly two-thirds were female in 2004. Among indigenous Alaska Scholars, over $70 \%$ were female.

In short, the roots of the postsecondary gender gap among Alaska Natives are found far earlier in the educational system and are pronounced among the most academically able students.

\section{Recent Changes in the Gender Gap among Alaska Natives}

The gender gap among Alaska Natives at the University of Alaska has increased over the last several years. While we present detailed year-by-year data in Table 2 for the convenience of other researchers who may wish to use this data for more fine-grained, comparative analyses, we also compare earlier fiscal years $(1998-2000)$ with the most fiscal recent years (2002-04) to illuminate possible trends in small populations (see Table 3). Among Alaska Natives, the proportion of male graduates has decreased at every level except associate (an unimportant change made larger by rounding conventions). The pattern among white males, in contrast, is mixed, depending on degree level. 


\section{DISCUSSION}

We suspect that the fundamental reason for the academic gender disparity among Alaska Natives is that school success and employment in occupations that require academic credentials are inconsistent with the traditional, prestigious male role as independent hunter and provider. Most educational programs in rural Alaska campuses focus on health, education, and office administration, occupations traditionally falling within the female role sphere (Kleinfeld and Andrews, 2005). Analyses of traditional gender roles among indigenous groups in Alaska and other regions of the circumpolar North emphasize gender role differentiation, with males responsible for hunting and females responsible for processing the products of the hunt (McElroy, 1975; Guemple, 1986; Condon and Stern, 1993). The traditional male role among Alaska Natives emphasized skills and virtues for which schooling is irrelevant, but which were vital to the community, making the difference between survival and starvation. These traditional skills remain important, partly in providing food from the land but also in providing a sense of cultural continuity and stability. At the same time that the transition to a mixed wage and subsistence economy is making hunting skills less vital to sheer survival, the communication and quantitative skills that schools provide are becoming more essential to the flourishing of indigenous communities. In Alaska, for example, Alaska Native groups participate in a vast network of organizations. These include the business corporations established by the Alaska Native Claims Settlement Act of 1971, nonprofit organizations that administer social services formerly handled by the Bureau of Indian Affairs, and national and international organizations that represent the political interests and needs of indigenous peoples across the globe. In this changing world, the educational attainment of indigenous people, both males and females, is crucial. But educational programs, particularly at the postsecondary level, are poorly adapted to the traditional cultural roles of Alaska Native males.

In an exploratory, qualitative effort to understand Alaska Native students' own explanations for the gender gap, we asked students in a required course at the University of Alaska Fairbanks to write papers in which they interviewed at least four personal friends or relatives about the reasons for the gender gap. The following themes frequently emerged in essays written by six Alaska Native students, three males and three females.

The Alaska Native students stated quite bluntly (and to us this is troubling) that one reason for the postsecondary gender gap is that females are "smarter" and "more mature" and goaloriented, while males are "lazy."

Women tend to be hard-working, more intelligent, and overall a lot more confident than men in what they are to do with their lives. I know of more women to turn in homework than men. I mean, look at me, for example.

(Male student)
TABLE 3. Comparison of the degree recipients at the University of Alaska by ethnicity, fiscal years 1998-2000 compared to fiscal years $2002-04 .^{1}$

\begin{tabular}{|c|c|c|c|c|}
\hline Ethnicity & Degree & Gender & $1998-2000$ & $2002-04$ \\
\hline Alaska Native & Certificate & Female & 156 & 137 \\
\hline \multirow{11}{*}{ /American Indian } & & Male & 42 & 31 \\
\hline & & $\%$ Male & 21 & 18 \\
\hline & Associate & Female & 158 & 217 \\
\hline & & Male & 50 & 69 \\
\hline & & $\%$ Male & 24 & 24 \\
\hline & Bachelor's & Female & 193 & 224 \\
\hline & & Male & 89 & 79 \\
\hline & & $\%$ Male & 32 & 26 \\
\hline & Master's & Female & 30 & 58 \\
\hline & & Male & 11 & 17 \\
\hline & & \% Male & 27 & 23 \\
\hline \multirow[t]{12}{*}{ White } & Certificate & Female & 157 & 183 \\
\hline & & Male & 155 & 127 \\
\hline & & $\%$ Male & 50 & 41 \\
\hline & Associate & Female & 1161 & 1131 \\
\hline & & Male & 667 & 731 \\
\hline & & $\%$ Male & 36 & 39 \\
\hline & Baccalaureate & Female & 1877 & 1798 \\
\hline & & Male & 1225 & 1134 \\
\hline & & $\%$ Male & 39 & 39 \\
\hline & Master & Female & 648 & 596 \\
\hline & & Male & 443 & 445 \\
\hline & & \% Male & 41 & 43 \\
\hline
\end{tabular}

${ }^{1}$ We omitted fiscal year 2001 to compare equal data sets from the three most recent years and the three earliest years for which we were able to obtain information. The data for fiscal year 2001 are in Table 2.

$$
\begin{aligned}
& \text { Women have the "brains." } \\
& \text { (Female student, quoting Alaska Native male } \\
& \text { whom she interviewed) }
\end{aligned}
$$

The second theme Alaska Native students used to explain the gender gap was that males were more apt to get into trouble with drugs, alcohol, and partying. A few also mentioned that young men were more apt to want to stay in the village where they could continue subsistence pursuits.

When guys enter college they want to party and procrastinate other than doing homework.

(Female student quoting Alaska Native male whom she interviewed)

Alcohol [and] drug abuse... are some distractions that play a big role in males not going off to college.

(Female student quoting Alaska Native male whom she interviewed)

What is troubling about some of these responses is the students' belief that Alaska Native males and females differ in intelligence and motivation. These responses reflect what psychologists call the "essentialist heuristic." As Prentice and Miller (2006:129) point out, "human beings are lay essentializers: they see many categories as 
having deep, nonobvious properties, or essences, that make category members the kinds of things they are." The Alaska Native students observe behavior that they interpret as "lazy," for example, and interpret this quality as intrinsic to males. Such essentialist theorizing is not limited to Alaska Native students. In explaining the gender gap in college attendance, students of other ethnic groups used the same essentialist labels for males and females. Students observe a phenomenon, such as young men not turning in homework or studying for tests, and conclude that "laziness" is an intrinsic characteristic of young males.

These are disturbing developments because they can easily turn into self-fulfilling prophecies, causing young Alaska Native men to conclude that "laziness" in respect to academic achievement is a male gender role expectation. The most effective way to change such essentialist conclusions is to change what young people observe and to offer educational programs interesting to young men as well as young women, programs in which young men do display concentrated effort.

We hypothesize that educational programs that reinforce traditional male roles and virtues, such as physical prowess, independence of action, and the performance of functions of obvious value to the family and community will offer a far higher probability of success for many young Alaska Native men than traditional, individualistic college programs. We conclude with the description of one such program at the University of Alaska Fairbanks, which offers a promising model for other efforts to draw indigenous men into postsecondary education.

\section{A Model Postsecondary Program for Increasing Academic Engagement among Young Men}

Recently, the University of Alaska began a new Construction Trades Technology (CTT) program, developed in part to create programs more attractive to Alaska Native men. Designed to develop a skilled local workforce in rural Alaskan villages, it offers a local cohort of rural Alaska Native young adults the opportunity to learn construction skills (Minogue, 2005b). This education is directly linked to paid employment on construction projects scheduled for the community. The education also benefits the community immediately. Students undertake a demonstration construction project that is locally useful, such as building a shelter for village-owned equipment. The instructor and students also repair people's homes: instructors help students get practice in the construction trade by doing small repair jobs for community residents, such as replacing shelves or weatherproofing sagging doors that let in cold air. The results of the CTT pilot program, replicated in a number of villages, suggest that this approach has considerable promise in increasing indigenous male enrollment in postsecondary education. By 2004, the CTT program had enrolled 217 students, of which $87 \%$ were male, and $85 \%$ were Alaska Natives. Furthermore, students enrolling in this program were primarily young adult men, ages 18 to 29 , the age group most underrepresented on Alaska's rural campuses.

The CTT program incorporates the following educational features that we suspect are crucial to its success:

a) It is located in the student's home community, so students do not have to leave their village, thus avoiding new distractions and obligations;

b) It offers cohort-based education enrolling most of the age group. Friends support each other, for example, going to homes to wake each other up so they come on time to a program that begins, as construction trades do, early in the morning;

c) It uses experienced instructors with practical, handson knowledge, who teach students not only skills but the lore of the trade, for example, that when supervisors yell at workers they are not necessarily angry but may be yelling because many older supervisors have lost much of their hearing;

d) It connects education to immediate employment, linking the education to construction projects scheduled for the community;

e) It embeds the development of literacy and numeracy in a practical context. Students in the CTT program, for example, develop writing skills by writing hypothetical letters to suppliers of construction materials.

f) It connects education to projects that show obvious and immediate benefit to the community and bring status and gratitude, for example, helping people with annoying home repair problems.

The education program itself makes young men feel that they are doing something useful and are needed by their community: it shows young men in the role of hard workers. This program is one example of educational approaches that connect students to school because the education is relevant, engaging, and challenging, a need that has been reported in national studies (Bridgeland et al., 2006.)

While other educational institutions, including many tribal colleges in the United States, offer various construction trades programs, these programs do not necessarily engage the young men as an intact peer group or offer them the opportunity to perform work of immediate and tangible value to local families and the community.

\section{CONCLUSION}

The gender gap favoring females in postsecondary education is both large and increasing among Alaska Natives. Employers, including those in rural circumpolar regions, increasingly seek people with highly developed verbal and symbolic skills and the ability to access and manage information. However, the issue goes beyond economic concerns. Less educated men have higher rates of unemployment, even in times of economic expansion, lower 
rates of marriage, higher rates of social problems, and lower rates of political participation (Sum et al., 2003). Developing ways to engage young Native men in education is vital to the sustainability of rural communities.

\section{REFERENCES}

BRIDGELAND, J., DiIULIO, J., and MORISON, K. 2006. The silent epidemic: Perspectives of high school dropouts. Washington, D.C.: Civic Enterprises.

CONDON, R., and STERN, P. 1993. Gender role preference, gender identity, and gender socialization among contemporary Inuit youth. Ethos 21(4):384-416.

FREEMAN, C.E. 2004. Trends in educational equity of girls and women: 2004 (NCES2005-016). Washington, D.C.: U.S. Department of Education, National Center for Education Statistics.

GERALD, D., and HUSSAR, W. 2003. Projections of education statistics to 2013. Washington, D.C.: U.S. Department of Education, National Center for Education Statistics.

GUEMPLE, L. 1986. Men and women, husbands and wives: The role of gender in traditional Inuit society. Études/Inuit/Studies 10(1-2):9-24.
KLEINFELD, J., and ANDREWS, J. 2005. The gender gap in the University of Alaska system. Unpubl. report available from the Northern Studies Program, University of Alaska, P.O. Box 756460, Fairbanks, Alaska 99775-6460.

McELROY, A. 1975. Canadian Arctic modernization and change in female Inuit role identification. American Ethnologist 2(4):662-686.

MINOGUE, S. 2005a. Education gap puts Inuit males at risk. Nunatsiaq News, 7 October.

- 2005b. Alaska program entices male dropouts back to school. Nunatsiaq News, 2 December.

PRENTICE, D.A., and MILLER, D.T. 2006. Essentializing differences between women and men. Psychological Science 17(2):129-135.

SUM, A., FOGG, N., and HARRINGTON, P. 2003. The growing gender gaps in college enrollment and degree attainment in the U.S. and their potential economic and social consequences. Boston: Center for Labor Market Studies, Northeastern University.

UN (UNITED NATIONS). 2004. Human Development Report 2004: Cultural liberty in today's diverse world. New York: United Nations Development Programme. 